\title{
Correction to: The impact of COVID-19 on surgical training: a systematic review
}

\author{
C. Hope ${ }^{1}$ (I) - J.-J. Reilly ${ }^{2}$ G. Griffiths ${ }^{3} \cdot$ J. Lund ${ }^{1} \cdot$ D. Humes ${ }^{4,5,6}$
}

Published online: 21 September 2021

(c) The Author(s) 2021

\section{Correction to: \\ Techniques in Coloproctology (2021) 25:505-520 \\ https://doi.org/10.1007/s10151-020-02404-5}

The article The impact of COVID-19 on surgical training: a systematic review, written by C. Hope, J.-J. Reilly, G. Griffiths, J. Lund, D. Humes, was originally published Online First without Open Access. After publication in volume 25 , issue 5 , pages 505-520 the author decided to opt for Open Choice and to make the article an Open Access publication. Therefore, the copyright of the article has been changed to $\odot$ The Author(s), 2021 and the article is forthwith distributed under the terms of the Creative Commons Attribution 4.0 International License, which permits use, sharing, adaptation, distribution and reproduction in any medium or format, as long as you give appropriate credit to the original author(s) and the source, provide a link to the
Creative Commons licence, and indicate if changes were made. The images or other third party material in this article are included in the article's Creative Commons licence, unless indicated otherwise in a credit line to the material. If material is not included in the article's Creative Commons licence and your intended use is not permitted by statutory regulation or exceeds the permitted use, you will need to obtain permission directly from the copyright holder. To view a copy of this licence, visit http://creativecommons. org/licenses/by/4.0/.

The original article has been corrected.

Open Access This article is licensed under a Creative Commons Attribution 4.0 International License, which permits use, sharing, adaptation, distribution and reproduction in any medium or format, as long as you give appropriate credit to the original author(s) and the source,
The original article can be found online at https://doi.org/10.1007/ s10151-020-02404-5.

\section{Hope}

carlahope@nhs.net

\section{J.-J. Reilly}

johnjoereilly@gmail.com

G. Griffiths

Gareth.griffiths@nhs.net

J. Lund

jon.lund@nottingham.ac.uk

D. Humes

David.humes@nottingham.ac.uk

1 Division of Medical Sciences and Graduate Entry Medicine, University of Nottingham, Derby DE22 3NE, UK
2 Queen's Medical Centre, Nottingham University Hospitals NHS Trust, Nottingham NG7 2UH, UK

3 Ninewells Hospital, Dundee, UK

4 Division of Epidemiology and Public Health, School of Medicine, University of Nottingham, Nottingham, UK

5 Nottingham Digestive Diseases Centre, School of Medicine, University of Nottingham, Nottingham, UK

6 National Institute for Health Research Nottingham Digestive Diseases Biomedical Research Unit, Nottingham University Hospitals NHS Trust, E Floor West Block, QMC Campus, Nottingham NG7 2UH, UK 
provide a link to the Creative Commons licence, and indicate if changes were made. The images or other third party material in this article are included in the article's Creative Commons licence, unless indicated otherwise in a credit line to the material. If material is not included in the article's Creative Commons licence and your intended use is not permitted by statutory regulation or exceeds the permitted use, you will need to obtain permission directly from the copyright holder. To view a copy of this licence, visit http://creativecommons.org/licenses/by/4.0/.

Publisher's Note Springer Nature remains neutral with regard to jurisdictional claims in published maps and institutional affiliations. 